\title{
Thorax Trauma Severity Score sebagai Prediktor Acute Respiratory Distress Syndrome pada Trauma Tumpul Toraks
}

\author{
${ }^{1}$ Hendry Soesanto, ${ }^{2}$ Adrian Tangkilisan, ${ }^{3}$ Ishak Lahunduitan \\ ${ }^{1}$ PPDS Ilmu Bedah Fakultas Kedokteran Universitas Sam Ratulangi Manado \\ ${ }^{2}$ KSM Ilmu Bedah Divisi Bedah Toraks Kardiovaskular RSUP Prof. Dr. R. D. Kandou \\ Manado \\ ${ }^{3}$ KSM Ilmu Bedah Divisi Bedah Anak RSUP Prof. Dr. R. D. Kandou Manado \\ Email: hendry_soesanto.aj@yahoo.com
}

\begin{abstract}
Thoracic trauma is a significant cause of mortality and morbidity. Difficulties in the management of blunt thoracic trauma patients are caused by the late presentation of acute respiratory distress syndrome (ARDS). Thorax trauma severity score (TTSS), introduced by Pape et al. in 2000, includes patient age, physiologic parameters, and thoracic radiological assessment. This study was aimed to assess the ability of TTSS in prediction of the occurence of ARDS in patients with blunt thoracic trauma. Statistical analysis performed was receiver operating characteristic (ROC) curve. In this study, there were 50 blunt thoracic trauma patients (45 males and 5 females), aged $\geq 18$ years old, admitted to Prof. Dr. R. D. Kandou Hospital during August 2016 to July 2017. Patients with penetrating thoracic trauma, history of any lung disease, and blunt thoracic trauma with onset $>24$ hours were excluded. The patient age range was 18-73 years with a mean of 39.02 years. Overall, 12 patients (24\%) developed ARDS, 9 patients (18\%) with pulmonary contusion, 20 patients $(40 \%)$ with rib fracture, 25 patients $(50 \%)$ with hematothorax, 6 patients (12\%) with pneumothorax, and 5 patients $(10 \%)$ with hypoxemia. TTSS got the most optimal value of sensitivity $(100 \%)$ and specifity (92.1\%) in cut-off point of 6 . Conclusion: TTSS can be used as a diagnostic tool to predict ARDS in blunt thoracic trauma.
\end{abstract}

Keywords: thorax trauma severity score, acute respiratory distress syndrome, blunt thoracic trauma

\begin{abstract}
Abstrak: Trauma toraks merupakan penyebab mortalitas dan morbiditas yang signifikan. Kesulitan penanganan pasien dengan trauma tumpul toraks disebabkan keterlambatan terdeteksinya acute respiratory distress syndrome (ARDS). Thorax trauma severity score (TTSS) yang diperkenalkan oleh Pape dkk pada tahun 2000 mencakup usia, parameter fisiologik, dan penilaian radiologik toraks. Penelitian ini bertujuan untuk menilai kemampuan TTSS dalam memrediksi kejadian ARDS pada pasien dengan trauma tumpul toraks. Analisis statistik menggunakan receiver operating characteristic (ROC) curve. Dalam studi ini terdapat 50 pasien dengan trauma tumpul toraks (45 laki-laki dan 5 perempuan), berusia $\geq 18$ tahun yang dirawat di RSUP Prof. Dr. R. D. Kandou pada Agustus 2016 s/d Juli 2017. Pasien dengan trauma tembus toraks, riwayat penyakit paru, dan trauma tumpul toraks dengan onset $>24$ jam tidak diikut sertakan dalam penelitian. Hasil penelitian mendapatkan rentang usia pasien 18-73 tahun dengan rerata 39,02 tahun. Terdapat 12 pasien (24\%) dengan ARDS, 9 pasien (18\%) dengan kontusio paru, 20 pasien (40\%) dengan fraktur kosta, 25 pasien (50\%) dengan hematotoraks, 6 pasien (12\%) dengan pneumotoraks, dan 5 pasien (10\%) dengan hipoksemia. TTSS mendapatkan nilai paling optimal dari sensitivitas (100\%) dan spesifitas $(92,1 \%)$ pada cut-off point 6 . Simpulan: TTSS dapat digunakan sebagai alat diagnostik untuk memrediksi kejadian ARDS pada pasien dengan trauma tumpul toraks.
\end{abstract}

Kata kunci: thorax trauma severity score, acute respiratory distress syndrome, trauma tumpul toraks 
Trauma toraks merupakan penyebab signifikan mortalitas dan morbiditas, terutama pada populasi usia muda. Kecelakaan lalu lintas (KLL) merupakan penyebab terbanyak trauma tumpul toraks dengan angka persentase mencapai hingga $70 \%$ pada beberapa studi. ${ }^{1}$

Kesulitan dalam pengelolaan pasien trauma tumpul toraks merupakan tantangan tersendiri dalam dunia medis. Pasien trauma tumpul toraks sering datang ke Instalasi Gawat Darurat (IGD) awalnya tanpa kesulitan pernapasan, tetapi dapat berkembang buruk mendapat komplikasi pernapasan sekitar 48 sampai 72 jam kemudian. Untuk itu diperlukan sebuah sistem penilaian yang dapat memrediksi komplikasi pada pasien trauma toraks. ${ }^{1,2}$

Pada tahun 2000 Pape et al. mengembangkan suatu sistem skoring yaitu thorax trauma severity score (TTSS) dengan menggabungkan usia pasien, parameter fisiologik, dan penilaian radiologis toraks. $^{3,4}$ Penelitian ini berujuan untuk menilai sensitivitas dan spesifisitas dari TTSS dan kemampuannya untuk memrediksi kejadian acute respiratory distress syndrome (ARDS) pada pasien trauma tumpul totaks.

\section{METODE PENELITIAN}

Jenis penelitian ini ialah deskriptif analitik dengan desain potong lintang. Hasil penelitian ini dianalisis dengan uji diagnostik deskriptif sehingga didapatkan nilai sensitivitas dan spesifisitas TTSS. Subjek penelitian ialah pasien yang berobat dengan trauma tumpul toraks yang berobat ke IRDB RSUP Prof. Dr R. D. Kandou dengan kriteria inklusi pasien berusia $\geq 18$ tahun, trauma tumpul toraks tanpa trauma pada anggota tubuh yang lain. Kriteria eksklusi ialah trauma tembus toraks, riwayat penyakit paru-paru (antara lain tuberkulosis paru), dan trauma tumpul toraks dengan onset $>24$ jam.

Prosedur penelitian diawali dengan pemeriksaan klinis, foto polos toraks AP tegak, dan analisis gas darah (AGD). Pemeriksaan foto polos toraks AP tegak dilakukan untuk menilai adanya kelainan anatomi pada toraks, seperti fraktur kosta, kelainan pleura (hematotoraks, pneumotoraks), dan kontusio paru. Pemeriksaan AGD dilakukan untuk menilai adanya kelainan fisiologik. Selanjutnya dilakukan penilaian TTSS dan observasi selama 7 hari terhadap tanda-tanda terjadinya ARDS.

\section{HASIL PENELITIAN}

Pada penelitian yang dilakukan di RSUP Prof. Dr. R. D. Kandou pada bulan Agustus 2016 s/d Juli 2017 didapatkan sampel 50 pasien yang memenuhi kriteria inklusi, terdiri dari 45 orang laki-laki (90\%) dan 5 orang perempuan (10\%) dengan rentang usia 18-73 tahun (rerata 39,02 tahun).

Tabel 1. Data pasien trauma tumpul toraks

\begin{tabular}{ll}
\hline \multicolumn{1}{c}{ Variabel } & \multicolumn{1}{c}{ Hasil } \\
\hline Usia & 39,02 tahun* \\
$\begin{array}{l}\text { Jenis kelamin } \\
\text { laki-laki : perempuan }\end{array}$ & $\begin{array}{l}\text { 45(90\%): 5(10\%) } \\
\text { ARDS }\end{array}$ \\
TTSS & $5,38^{*}$ \\
Kontusio paru & 9 kasus $(18 \%)$ \\
Fraktur kosta & 20 kasus $(40 \%)$ \\
Hematotoraks & 25 kasus $(50 \%)$ \\
Pneumotoraks & 6 kasus $(12 \%)$ \\
Hipoksemia & 5 kasus $(10 \%)$ \\
\hline
\end{tabular}

*Nilai mean

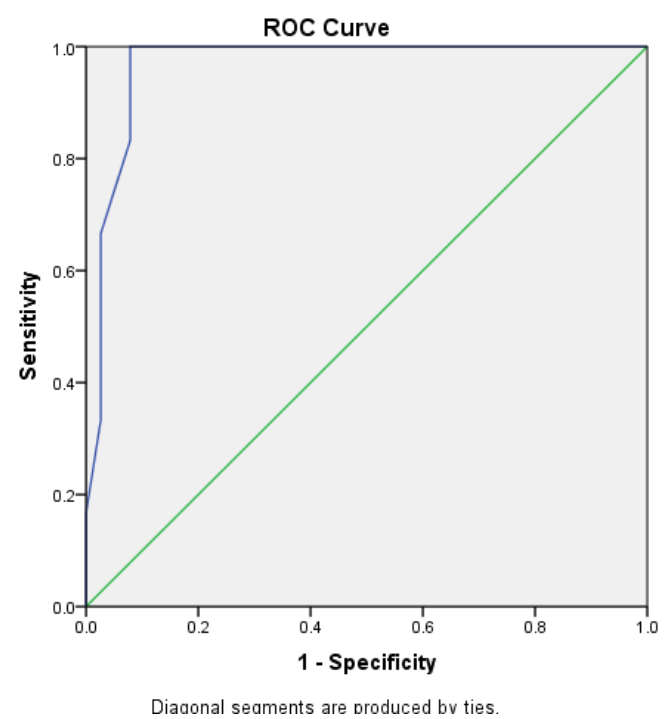

Gambar 1. Diagram hubungan TTSS dengan ARDS 


\section{BAHASAN}

Sebagian besar sampel dalam penelitian ini berjenis kelamin laki-laki (90\%). Rerata usia sampel ialah 39,02 tahun yang merupakan usia produktif dimana sebagian besar orang memiliki mobilitas tinggi dengan kendaraan bermotor. Hal ini sesuai dengan penyebab trauma tumpul toraks kebanyakan disebabkan oleh KLL. Lakilaki sebagian besar beraktivitas di luar rumah sehingga kemungkinan untuk mengalami kecelakaan lalu lintas juga lebih tinggi. ${ }^{5}$

Pada penelitian ini didapatkan kejadian ARDS sebanyak 12 pasien (24\%) dan nilai rerata TTSS sebesar 5,38. Hal ini membuktikan sebagian besar cedera trauma tumpul toraks tergolong kategori ringan; hanya sebagian kecil yang berkembang menjadi ARDS.

Dari data yang didapatkan, fraktur kosta ditemukan pada 20 pasien (40\%). ARDS terjadi pada pasien dengan fraktur kosta ( $>4$ kosta) sebanyak 12 dari 13 pasien ARDS (92,3\%). Banyaknya fraktur kosta berkorelasi juga dengan banyaknya mediator pro inflamasi yang dilepaskan, sehingga bepeluang untuk berkembang menjadi ARDS. ${ }^{1,6,7}$

Hasil yang diperoleh memperlihatkan pada 25 pasien (50\%) terdapat hematotoraks dan pada 6 pasien (12\%) terdapat pneumotoraks. Sebanyak 6 pasien (12\%) hematotoraks dan 1 pasien (2\%) pneumotoraks berkembang menjadi ARDS. Dapat disimpulkan baik hematotoraks maupun pneumotoraks jarang merupakan penyebab utama terjadinya ARDS. Diperlukan trauma pada organ lain seperti kosta dan paru untuk memperburuk keadaan menjadi ARDS.

Pada penelitian ini, dari 50 pasien terdapat 9 (18\%) yang mengalami kontusio paru. ARDS terjadi pada $100 \%$ kasus kontusio paru setelah selang waktu 24-48 jam. Hal ini dikarenakan produksi dan pelepasan mediator pro inflamasi yang paling banyak pada fase awal trauma. Peningkatan pelepasan mediator proinflamasi kemudian menginduksi infiltrasi neutrofil ke paru-paru yang nantinya menyebabkan ARDS, yang sangat terkait dengan peningkatan morbiditas dan mortalitas pada trauma tumpul toraks. ${ }^{1,6-8}$

Pengelolaan pasien trauma tumpul toraks dengan kontusio paru menjadi tantangan karena biasanya pada evaluasi awal pasien datang dengan kondisi klinis yang masih baik dan tanpa hipoksemia tetapi memburuk pada 24-48 jam pasca trauma dan berkembang menjadi ARDS yaitu sekitar $15,5 \% .^{9-11}$ Pada penelitian yang dilakukan, dari kelompok hipoksemia sebanyak 5 pasien (10\%) saat pemeriksaan klinis awal, semuanya berkembang menjadi ARDS, sedangkan dari kelompok nonhipoksemia sebanyak 45 pasien (90\%), 7 pasien (15,55\%) di antaranya mengalami ARDS. Populasi non-hipoksemia (90\%) ini yang merupakan risiko tinggi bagi klinisi untuk salah menilai dan memperkirakan perburukan klinis dari pasien. Hal ini menyokong semakin pentingnya skor trauma tumpul toraks sebagai alat diagnostik awal yang handal untuk deteksi dini dalam memrediksi terjadinya ARDS.

Dari data penelitian yang didapatkan, skor TTSS dapat dikaitkan secara bermakna dengan terjadinya ARDS. Dari 13 pasien dengan skor TTSS tinggi, terdapat 10 pasien yang terbukti ARDS. Sensitivitas dan spesifisitas TTSS dalam memrediksi ARDS pada trauma tumpul toraks yang tinggi (sensitivitas 100\% dan spesifisitas 92\%) pada TTSS sebesar 6, membuktikan bahwa TTSS dapat dipakai sebagai salah satu alat diagnostik awal yang akurat pada kasus trauma tumpul toraks.

Mommsen et al. ${ }^{12}$ melakukan penelitian dengan memakai TTSS untuk mendeteksi adanya komplikasi pernafasan pada pasien multi trauma, namun dengan akurasi yang tidak terlalu baik, yaitu sensitivitas $63 \%$ dan spefisitas $74 \%$ pada cut-off point 8. Casas et al. ${ }^{4}$ menilai pemakaian TTSS untuk mendeteksi komplikasi pernafasan pada trauma toraks tajam maupun tumpul. Hasil akurasi yang diperoleh kurang memuaskan, yaitu sensitivitas 63\% dan spesifisitas 94\% dengan cut-off point 8. Elbaih et al. ${ }^{6}$ menggunakan TTSS untuk 
mendeteksi mortalitas pada trauma tumpul toraks dan mendapatkan akurasi yang tinggi yaitu sensitivitas $100 \%$ dan spesifitas $100 \%$ dengan cut-off point 7.

Keunggulan TTSS sebagai skor yang dapat memprediksi ARDS pada trauma tumpul toraks disebabkan sistem penilaian yang meliputi penilaian anatomis (pleura, paru, dan kosta), penilaian parameter fisiologik ( $\mathrm{PaO} 2 / \mathrm{FiO} 2)$ dan juga karakteristik pasien (usia) dipertimbangkan. Skor ini juga mudah dilakukan oleh klinisi sebagai skirining awal pada pasien trauma tumpul toraks. 1,2,4,12-15 Dianjurkan untuk menggunakan TTSS sebagai alat diagnostik awal dalam memrediksi ARDS pada kasus trauma tumpul toraks. Deteksi dini risiko ARDS merupakan penentu untuk dijadikan pemandu manajemen awal dan keperluan ventilasi mekanik.

Penelitian ini memiliki beberapa keterbatasan yang harus diperhitungkan. Intervensi bedah merupakan salah satu faktor bias yang tidak dapat dipungkiri. Tindakan bedah sendiri dapat merupakan tindakan yang memperbaiki keadaan pasien, namun dapat juga meningkatkan faktor-faktor proinflamasi yang nantinya dapat memicu terjadinya ARDS. Diperlukan penilaian lanjutan yang dapat memasukkan tindakan bedah dalam sistem skoring yang ada.

\section{SIMPULAN}

Thorax trauma severity score (TTSS) dapat menjadi alat diagnostik dalam memrediksi kejadian ARDS pada kasus trauma tumpul toraks.

\section{DAFTAR PUSTAKA}

1. Elbaih AH, Elshapowry IM, Kalil NG, ElAouty H. Evaluation of thoracic trauma severity score in predicting the outcome of isolated blunt chest trauma patients. IJSM. 2016;2(3):100-6.

2. Battle $C$, Hutchings $H$, Lovett $S$, Bouamra $\mathbf{O}$, Jones S, et al. Predicting outcomes after blunt chest wall trauma: development and external validation of a new prognostic model. Crit Care. 2014; 18:R98.

3. Pape H, Sanders R, Borrelli J. Poly traumatized patient with fracture: multi diciplinery approach. Heidelberg Berlin: Springer-Verlag, 2011.

4. Casas IM, Marchante MAA, Paduraru M, Olea AIF, Nolasco A, Medina JC. Thorax trauma severity score: Is it reliable for patient's evaluation in a secondary level hospital? Bull Emerg Trauma. 2016;4(3):150-5.

5. Gopinath $\mathbf{N}$. Thoracic trauma. IJTCVS. 2004;20(3):144-8.

6. Mattox K, Moore E, Feliciano D. Trauma (7th ed). USA: McGraw-Hill, 2013.

7. Raghavendran $K$, Notter $R$, Davidson $B$, Helinski J, Kunkel S, Knight P. Lung contusion: inflammatory mechanisms and interaction with other injuries. Shock. 2009;32(2):122-30.

8. Ganie F, Lone H, Lone G, Wani M, Singh S, Majeed Dar A, et al. Lung contusion: a clinico-pathological entity with unpredictable clinical course. Bull Emerg Trauma. 2013;1(1):7-16.

9. Bakowitz M, Bruns B, McCunn M. Acute lung injury and the acute respiratory distress syndrome in the injured patient. SJTREM. 2012;20:54.

10. Fanelli V, Vlachou A, Ghannadian S, Simonetti U, Slutsky A, Zhang H, et al. Acute respiratory distress syndrome: new definition, current and future therapeutic options. J Thorac Dis. 2013;5(3):326-34.

11. Ferguson N, Fan E, Camporota L, Antonelli M, Anzueto A, Beale R. The Berlin definition of ARDS: an expanded rationale, justification, and supplementary material. Intensive Care Med. 2012; 38:1573-82.

12. Mommsen P, Zeckey C, Andruszkow H, Weidemann J, Fromke C, Ouljic P, et al. Comparison of different thoracic trauma scoring systems in regards to prediction of post-traumatic complications and outcome in blunt chest trauma. J Surg Res. 2012;176(1):239-47.

13. Pharaon K, Marasco S, Mayberry J. Rib fractures, flail chest, and pulmonary contusion. Curr Trauma Rep. 2015;1:237-42.

14. Huber S, Biberthaler P, Delhey $P$, Trentzsch $\mathbf{H}$, Winter $\mathbf{H}$, Griensven $M$, et al. Predictors of poor outcomes after significant chest trauma in multiply injured patients: a retrospective analysis from the German Trauma Registry. 
38 Jurnal Biomedik (JBM), Volume 10, Nomor 1, Maret 2018, hlm. 34-38

SJTTREM. 2014;22:52.

15. Daurat A, Millet I, Roustan J, Maury C, Taourel P, Jaber S, et al. Thoracic trauma severity score on admission allows to determine the risk of delayed ARDS in trauma patients with pulmonary contusion. Injury. 2016;47:147-53. 